\title{
ANALYSIS OF THE RESISTANCE OF GRAIN PESTS TO PHOSPHINE. REVIEW
}

\author{
Gennady A. Zakladnoy \\ All-Russian Scientific Research Institute for Grain and Products of its Processing - \\ Branch of the V. M. Gorbatov Federal Research Center for Food Systems of RAS, Moscow, Russia
}

KEY WORDS:

grain, insects, phosphine, resistance

\begin{abstract}
Resistance of stored grain pests to phosphine is a problem that is being treated in many countries of the world. This is due to the fact that this fumigant is the most widely used in the world. The review shows the resistance of a number of major pests to phosphine from the initial to the high degree of resistance due to its importance for practical use in the protection of stored grain. The analysis of the search and use of alternative fumigants has been given, the reasons for their refusal to use them have been formulated. The causes of the emergence of resistant insect populations at high concentrations of phosphine are described and measures to overcome resistance are proposed. It is shown that this circumstance leads to inefficiency of the application of existing fumigation regulations by phosphine in warehouses and elevators, in metal silos, in wagons on the way, in the holds of smallton and large-capacity vessels in the voyage. It is concluded that only a comprehensive approach to research to identify the causes of the emergence of resistance of stored product pests to phosphine will help to avoid the abandonment of the use of phosphine in Russia and other countries. This circumstance will avoid large losses in the grain industry.
\end{abstract}

\section{Introduction}

Since the development of the biological basis of the use of phosphine gas in Russia [1], it has been updated in the regulatory document for more than 20 years [2]. Phosphine is the only gas allowed in Russia [3,4] to decontaminate grain in warehouses and elevators [5], in metal silos [6], in wagons on the way [7], in the holds of small-ton vessels in a voyage [8], in the holds of largecapacity vessels in a voyage [9], as well as the grain storages and grain processing plants [1,2].

In recent years, according to experts of elevator companies and fumigation companies, often there are problems with phosphine fumigation of grain and the premises of processing plants. These failures were usually attributed to the uneven distribution of phosphine in the grain mound, possible violations of gas regulations or phosphine leaks due to insufficient air tightness of the premises. On the latter occasion we conducted special research and published data on the actual large leaks of phosphine in real fumigation of mills in Russia [10].

The publications $[11,12]$ described the problems of acquired resistance (further - resistance) of arthropods to various pesticides, identified resistance as an increased ability of pests to carry pesticides, and named the following three factors that cause resistance:

1) The use of pesticide in sublethal doses, especially systematic, for a number of generations, leads to the death of the most sensitive individuals and the survival of the most resistant to the poison. So the selection of resistant individuals is formed, which give resistant offspring;

2) In addition to selection, because of the effects of poison in insects can develop useful adaptations that allow to tolerate the destructive effects of poison and survive;

3) The genetic factor associated with the mutagenic effects of chemicals may also influence the increase in resistance in insects to pesticides. This has been a particular consideration in recent years [13].

The purpose of this review is to show the state with resistance to the phosphine of the pests of stored product pests in the world and the danger of this phenomenon for Russia.

\section{Main part}

2.1. Assessment of pest resistance to phosphine

In 1976, the UN FAO report on the Global Review of Resistance was published [14]. At that time, this phenomenon was observed in pests of stored products in 33 of the 82 countries surveyed. More resistance was to contact insecticides than to fumigants. So its first registration was made at Tribolium castaneum to malathion in Australia, in the state of Queensland on peanuts.

FAO has recommended a method for assessing insect resistance to pesticides [15] so that data from different laboratories can be compared. The technique includes three stages:

1) Assessment of dose-mortality dependence in a sensitive standard laboratory line of insects previously do not in contact with pesticides to establish LD-50, LD-99.9 (lethal doses causing the death of $50 \%$ and $99.9 \%$ of individuals in the population) and control (discriminatory) dose, which should slightly exceed LD-99.9;

2) Testing unknown insect lines for resistance to a discriminatory dose of pesticide to conclude their resistance compared to the standard line;

3) Establishing dose-mortality dependency by probit analysis in resistant lines and comparing it with data for the standard line.

The assessment of resistance has become widely popular in the world due to its importance for the practice of protecting grain from pests.

By 2000, 11 major stored product pest species had been found to be highly resistant [16]. By 2003, Liposcelis bostrychophila Badonnel (Psocoptera: Liposcelididae) had been found severely resistant to phosphine [17].

Over the past few decades, the situation in the world has deteriorated both in of frequency and terms resistance $[18,19$, $20,21,22,23,24]$. In most cases, the development of increased resistance is associated with inadequate fumigation, including poor sealing and repeated fumigation. Studies in the past decade have revealed strong phosphate resistance in a number of pests of stored products [22 23, 24, 25]. 
Against these pests, the usual regimes of use of phosphine were ineffective and had to work out new regulations. For this reason, the traditional FAO methodology [15] for identifying severe resistance has not been fully adequate and has since been gradually adjusted $[25,26]$. A plenary report at a conference [27] stated that the key to successful management of increased phosphine resistance lies in its early diagnosis and proper characterization. It is noted that $[28,29]$ Australia has adopted and successfully implemented a national resistance monitoring Programme since the 1980s, and the country is unique in this. At the same time, there is a steady annual increase in the incidence of resistance detection. That's why Australians are constantly following the trends and geography of resistance in the country [30, 31, 32].

Following the UN FAO review [14], the most comprehensive resistance survey has been undertaken in a number of Moroccan granaries. Its results were published in 2002 [33], which reported a strong and frequent increased resistance to phosphine in $T$. castaneum, Rhyzopertha dominica and S. oryzae. A smaller survey was conducted five years later in Brazil [24], where 14 of the $19 \mathrm{Rh}$. dominica populations studied had severe resistance to phosphine.

It is very important for countries that use phosphine to disinfect stored products to regularly monitor pesticide resistance in key pests. Late detection of severe resistance to phosphine will no longer help. Detection of the onset of increased resistance will provide an opportunity to eradicate this population, as well as give time to develop adjusted regulations for the use of phosphine and its alternatives.

\subsection{Alternatives to phosphine}

Experts know that the widespread use in the world phosphine took after the restriction by the famous Montreal Protocol of 1987 the use of methyl bromide for fumigation of stored products as a destructive substance ozone layer of the atmosphere [34].

After the discovery of the widespread resistance of insects to phosphine, various attempts were made to find new alternative fumigants. Among them, the most promising was fluoride sulfuril $\left(\mathrm{SO}_{2} \mathrm{~F}_{2}\right)$, which has a wide range of actions against pests. It has been registered in Australia for fumigation of grain processing and food processing plants, dried fruits and stored grains [27]. In addition, there is evidence that insect resistance to phosphine does not extend to their resistance to fluoride sulfuriles [35]. However, fluoride sulfuril has in some experiments shown a weak effect on the eggs of stored product pests [36, 37].

Another alternative fumigant, carbon dioxide $\left(\mathrm{CO}_{2}\right)$, has the prospect of rapid disinsection only at high pressure, but the high cost of high-pressure cameras limits its use [38].

The paper [39] reports on the effectiveness of carbonyl sulfide (SOS) against a number of pests of stored products. However, the later article [40] published about the weak effects of this gas on $S$. oryzae. Among its other limitations, it points to the oppression of the vitality of seeds and to the foreign smell acquired by the products after fumigation [41].

In experiments [42], it has been found that ethyl formiate $\left(\mathrm{NSO}_{2} \mathrm{~N}_{5}\right.$ ) (ethyl ester of ant acid) can also produce a good disinfectant effect, but only in combination with carbon dioxide. When used independently, it is little effective against a number of pests. But the main danger lurks in its high capacity to ignite.

Good old-time cyanide (HCN) is highly toxic to insects [43, 44], but it is criticized for its strong grain sorbation [41].

Rather extensive publications are devoted to the cyanogen $(\mathrm{CN})_{2}$ $[45,46,47,49,50,51,52,53]$, which established the high efficiency of this gas in suppressing insects that harm grain. However, there are indications of its phytotoxicity, which threatens the viability of the grain $[41,54]$.

The controlled modified atmosphere with an increased carbon dioxide content, almost supplanted by oxygen and high nitrogen content can be recognized as an alternative to other fumigants which is devoted to extensive scientific literature in our country. $[55,57,58,59,60]$ and abroad, where specialized international conferences are held periodically every four years under the title «Controlled Atmosphere and Fumigation» (CAF) and proceedings of these conferences are published. A certain drawback here is too long time, which requires insects to suffocate in a controlled atmosphere [61].

\subsection{Assessment of the future and recommendations}

Due to the high and ever-expanding worldwide resistance of insects to phosphine [62], there is a serious problem of the possibility of its use in the foreseeable future. What steps are the scientific world considering in prolonging this future?

One of the key solutions is the correct use in the applicable regulations of the combination of phosphine concentration and fumigation exposure time [63]. Studies have also clearly demonstrated the effect of temperature on the effectiveness of phosphine $[64,65]$. These factors should be directly taken into account when managing the effectiveness of phosphine against resistant pest populations. For example, in Australia, after the strong and extensive resistance of local pest populations to phosphine, new regulations on the use of phosphine have been developed and implemented to overcome the identified resistance $[66,67]$.

There are successes in understanding the molecular aspects of phosphine resistance $[68,69,70]$.

It has been established that at least two main genes control a high level of phosphine resistance in $\mathrm{Rh}$. dominica [71] and T. castaneum [72]. A detailed genetic and molecular analysis of $R h$. dominica [73] found the presence of two loci (locations) rph1 and rph2 on the genetic map of the chromosome responsible for the resistance of this insect. Rph1 controls the phenotype with «weak» resistance, providing moderate resistance to phosphine. $R p h 2$ itself determines only a very low level of resistance. $R p h 2$ was not detected until rph1 became common, and until both locus were combined into the same individual and synergies produced a higher level of resistance, known as the «strong» phenotype of resistance.

This discovery led to a series of additional genetic experiments to determine whether the $R h$. dominica populations, far apart geographically, form the same genes for the development of strong resistance $[74,75]$. The results confirmed this hypothesis. At the same time, it has been shown [76] that if an insect flies over, a gene flies with it.

\section{Conclusion}

The results of the study showed that the following activities should be envisaged in our country:

1. To develop and implement a national Programme to monitor the resistance of key food pests to phosphine;

2. To identify the factors responsible for the development of resistance;

3. To reduce selection, i. e. to limit the number of fumigations by phosphine;

4. To eliminate detected resistant populations in enterprises by using alternative methods;

5. To develop plans to eradicate and follow these recommendations for the use of phosphine by all participants in the grain industry. 


\section{REFERENCES}

1. Zakladnoy, G. A., Szeltova, S. A. (1987). Biological bases of phosphine use to control insects - pests of bread stocks. Proceedings of All-Russian Scientific and Research Institute for Grain and Products of Its Processing, 87-93. (in Russian)

2. Instructions for pest control of stored grain. (1992). [Electronic resource: http://www.alppp.ru/law/hozjajstvennaja-dejatelnost/promyshlennost/21/instrukcija-po-borbe-s-vrediteljami-hlebnyh-zapasov.pdf Access date 21.01.2020] (in Russian)

3. State catalogue of pesticides and agrochemicals allowed for use in the Russian Federation. [Electronic resource: https://www.garant.ru/products/ipo/prime/doc/71833632/ Access date 15.01.2020] (in Russian)

4. Zakladnoy, G. A. (2018). Phosphine. Moscow: Center for training specialists. -186 p. ISBN: 978-5-6040056-2-0 (in Russian)

5. Zakladnoy, G. A. (2018). Fumigation of grain with phosphine in warehouses and elevators. Moscow: Center for training specialists. $-69 \mathrm{p}$ ISBN: 978-5-6040056-8-2 (in Russian)

6. Zakladnoy, G. A. (2019). Fumigation of grain with phosphine in metal siloes. M: Center for training specialists. - 110 p. ISBN: 978-5-60400561-3 (in Russian)

7. Zakladnoy, G. A. (2020). Fumigation of grain with phosphine in wagons on the way. Moscow: Center for training specialists. - 64 p. ISBN: 9785-6040056-6-8 (in Russian)

8. Zakladnoy, G. A. (2018). Fumigation of grain with phosphine in holds of small-capacity vessels in the voyage. Moscow: Center for training specialists. - 80 p. ISBN: 978-5-6040056-4-4 (in Russian)

9. Zakladnoy, G. A. (2018). Fumigation of grain with phosphine in holds of large-capacity vessels in the voyage. Moscow: Center for training specialists. - 97 p. ISBN: 978-5-6040056-0-6 (in Russian)

10. Zakladnoy, G. A., Dogadin A. L. (2014). Problems with fumigation of mills in Russia. Bread products, 12, 39. (in Russian)

11. Zakladnoy, G. A., Ratanova, V. F. (1973). Pests of stored product and measures to control them. Moscow: Kolos. - 287 p. (in Russian)

12. Zakladnoy, G. A. (1983). Protecting grain and its processing products from pests. Moscow: Kolos. - 212 p. (in Russian)

13. Huang, Y., Li, F., Liu, M., Wang, Y., Shen, F., Tang, P. (2019). Susceptibility of Tribolium castaneum to phosphine in China and functions of cytochrome P450s in phosphine resistance. Journal of Pest Science, 92(3), 1239-1248. https://doi.org/10.1007/s10340-019-01088-7

14. Champ, B. R., Dyte, C. E. (1976). Report on the FAO global survey of pesticide susceptibility of stored grain pests. FAO Plant Protection and Production Services No. 5, FAO Rome.

15. Food and Agriculture Organization. Recommended methods for detection and measurement of resistance of agricultural pests to pesticides tentative method for adults of some major pest species of stored cereals, with methyl-bromide and phosphine - FAO Method No 16. (1975) FAO Plant Prot. Bull, 23, 12-25.

16. Chaudhry, M. Q. (2000). Phosphine resistance. Pesticide Outlook, 11(3), 88-91. https://doi.org/10.1039/b006348g

17. Nayak, M. K., Collins, P. J., Pavic, H., Kopittke, R. A. (2003). Inhibition of egg development by phosphine in the cosmopolitan pest of stored products Liposcelis bostrychophila (Psocoptera: Liposcelididae). Pest Management Science, 59(11), 1191-1196. https://doi.org/10.1002/ps.753

18. Srivastava, J. L. (1980). Pesticide residue in foodgrains and pest resistance to pesticides. Bull. Grain Technology, 18(1), 65-76.

19. Mills, K. A. (1983). Resistance to the fumigant hydrogen phosphine in some stored-product species associated with repeated inadequate treatments. Mitteilungen der Deutschen Gesellschaft für allgemeine und angewandte Entomologie, 4, 98-101.

20. Taylor, R. W. D. (1989). Phosphine - a main fumigant at risk. International Pest Control, 31, 10-14.

21. Zettler, J. L. (1996). Influence of resistance of future fumigation technology. Proceedings of the International Conference on Controlled Atmosphere and Fumigation in Stored Products. Nicosia, Cyprus, 445-454.

22. Nayak, M. K., Collins, P. J., Pavic, H. (2003). Development in phosphine resistance in China and possible implications for Australia. Proceedings of the Australian Postharvest Technical Conference, Canberra, 25-27 June 2003. CSIRO Stored Grain Research Laboratory, Canberra, 156-159.

23. Collin, P. J., Daglish, G. J., Pavic, H., Kopittke, R. A. (2005). Response of mixed-age cultures of phosphine-resistant and susceptible strains of lesser grain borer, Rhyzopertha dominica to phosphine at a range of concentrations and exposure periods. Journal of Stored Products Research, 41(4), 373-385. https://doi.org/10.1016/j.jspr.2004.05.002

24. Lorini, I., Collins, P. J., Daglish, G. I., Nayak, M. K., Pavic, H. (2007). Detection and characterisation of strong resistance to phosphine in Brazilian Rhyzopertha dominica (F.) (Coleoptera: Bostrychidae). Pest Management Science, 63(4), 358-364. https://doi.org/10.1002/ps.1344

25. Botta, P., Botta, C., Warrick., C. (2012). Improving the efficacy of phosphine fumigation in on farm storage in South Eastern Australia. Proceedings of the $9^{\text {th }}$ International Conference on Controlled Atmosphere and Fumigation in Stored Products, Antalya, Turkey, 620-616.

26. Nayak, M. K., Holloway, J. C., Emery, R. N., Pavic, H., Bartlet, J., Collins, P. J. (2013). Strong resistance to phosphine in the rusty grain beetle, Cryptolestes ferrugineus (Stephens) (Coleoptera: Laemophloeidae): its characterisation, a rapid assay for diagnosis and its distribution in Aus- tralia. Pest Management Science, 69(1), 48-53. https://doi.org/10.1002/ ps.3360

27. Nayak, M. K. (2012). Managing resistance to phosphine in storage pests challenges and opportunities. Proceedings of the $9^{\text {th }}$ International Conference on Controlled Atmosphere and Fumigation in Stored Products, Antalya, Turkey, 609-616.

28. Emery, R. N., Nayak, M. K., Holloway, J. C. (2011). Lessons learned from phosphine resistance monitoring in Australia. Stewart Postharvest Review, 7(3), 8. https://doi.org/10.2212/spr.2011.3.8

29. Collins, P. J., Emery, R. N. (2002). Two decades of monitoring and manag ing phosphine resistance in Australia. Proceedings $8^{\text {th }}$ International Work ing Conference on Stored Product Protection, CAB International, Wallington, UK, $570-575$.

30. Collins, P. J., Falk, M. G., Nayak, M. K., Emery, R. N., Holloway, J. C. (2017) Monitoring resistance to phosphine in the lesser grain borer, Rhyzopertha dominica, in Australia: A national analysis of trends, storage types and geography in relation to resistance detections. Journal of Stored Products Research, 70, 25-36. https://doi.org/10.1016/j.jspr.2016.10.006

31. Nayak, M. K., Falk, M. G., Emery, R. N., Collins, P. J., Holloway, J. C. (2017) An analysis of trends, frequencies and factors influencing the development of resistance to phosphine in the red flour beetle Tribolium castaneum (Herbst) in Australia. Journal of Stored Products Research, 72, 35-48. https://doi.org/10.1016/j.jspr.2017.03.004

32. Schlipalius, D. I., Tuck, A. G., Pavic, H., Daglish, G. J., Nayak, M. K., Ebert, P. R. (2019). A high-throughput system used to determine frequency and distribution of phosphine resistance across large geographical regions. Pest Management Science, 75(4), 1091-1098. https://doi.org/10.1002/ps.5221

33. Benhalima, H., Chaudhry, M. Q., Mills, K. A., Price, N. R. (2002). Phosphine resistance in stored-product insects collected from various grain storage facilities in Morocco. Journal of Stored Products Research, 40(3), 241-249. https://doi.org/10.1016/S0022-474X(03)00012-2

34. Muller, D. K. (1998.). Stored product protection... A Period of Transition. USA: Insects Limited, Inc. -348 p.

35. Jagadeesan, R., Nayak, M. K. (2017). Phosphine resistance does not confer cross-resistance to sulfuryl fluoride in four major stored grain insect pests. Pest Management Science, 73(7), 1391-1401. https://doi. org/10.1002/ps.4468

36. Drinkall, M. J., Dugast, J. F., Reichmuth, C., Scholler, V. (1996). The activity of the fumigant sulfuryl fluoride on stored product insect pests. Proceedings $2^{\text {nd }}$ International Conference Insect Pests in the Urban Environment, Cambridge, UK, 525-528.

37. Bell, C. H. (2000). Fumigation in the $21^{\text {st }}$ century. Crop Protection, $19(8-$ 10), 563-569. https://doi.org/10.1016/S0261-2194(00)00073-9

38. Prozell, S., Reichmuth, C., Ziegleder, G., Schartmann, B., Matissek, R., Kraus, J., Gerard, D., Rogg, S. (1996). Control of pests and quality aspects in cocoa beans and hazel nuts and dilution experiments in compressed tobacco with carbon dioxide under high pressure. Proceedings of the International Conference on Controlled Atmosphere and Fumigation in Stored Products. Nicosia, Cyprus, 325-333.

39. Desmarchelier, J. M. (1994). Carbonyl sulphide as a fumigant for control of insects and mites. Proceedings $6^{\text {th }}$ International Working Conference on Stored Product Protection, CAB International, 78-82.

40. Rajendran, S. (2001). Alternatives to methyl bromide as fumigant for stored food commodities. Pesticide Outlook, 12(6), 249-253. https://doi. org/10.1039/b110550g

41. Navarro, S. (2006). New global challenges to the use of gaseous treatment in stored products. Proceedings $9^{\text {th }}$ International Working Conference on Stored Product Protection, Campinas, Brazil, 495-509.

42. Haritos, V. S., Damcevski, K. A., Dojchinov, G. (2006). Improved efficacy of ethyl formate against stored grain insects by combination with carbon dioxide in a dynamic application. Pest Management Science, 62(4), 325-333. https://doi.org/10.1002/ps.1167

43. Instructions for pest control stocks of grain, flour and groats. Moscow: CINTI Goskomzaga USSR.1965, - 135 p. (in Russian)

44. Eremenko, V. M., Brudnaya, A. A., Men'shova, L. P., Ratanova, V. F. Solodovnik, P. S., Sosedov, N. I. (1967). Guide to pest control of stored products. Moscow: Kolos. - 336 p. (in Russian)

45. Hooper, J. L., Desmarchelier, J. M., Ren, Y., Allen, S. E. (2003). Toxicity of cyanogens to insects of stored grain. Pest Management Science, 59(3), 353-357. https://doi.org/10.1002/ps.648

46. CSIRO and The University of Canberra, Cyanogen fumigants and methods of fumigation using cyanogen, International Patent Application PCT/ AU95/00409 (1995).

47. Braker, W., Mossman, A. L. (1971). Matheson gas data book. Matheson Gas Production-Will Ross Inc., New Jersey. $-574 \mathrm{p}$.

48. Ren, Y., Trang, L. V. (2002). Cyanogen: a possible fumigant for flour/rice mills and space fumigation. Proceedings $8^{\text {th }}$ International Working Conference on Stored Product Protection, 651-653.

49. Sarvar, M., Mahon, D., Ren, Y. (2003). Interaction of ethanedinitrile $\left(\mathrm{C}_{2} \mathrm{~N}_{2}\right)$ with contact materials used in grain storage. Proceedings of the Australian Postharvest Technical Conference, Canberra, 25-27 June 2003. CSIRO Stored Grain Research Laboratory, Canberra, 1-3.

50. Robbiola, L., Queixalos, I., Zwick, A., Basle, K., Daniel, F., Drieux-Daguerre, M., Ducom, P. J. F., Fritsch, J. (2015). Disinfestation of historical 
buildings - corrosion evaluation of four fumigants on standard metals. Journal of Cultural Heritage, 16(1), 15-25. https://doi.org/10.1016/j.culher.2014.02.004

51. Ren, Y., Desmarchelier, J. M., Watson, F. (1997). Effect of Grain fumigation on Lipid in Vivo and in Vitro. Journal of Agricultural and Food Chemistry, 45(7), 2626-2629. https://doi.org/10.1021/if960917a

52. Smith, B. J., Ren, Y., Waterford, C. J. (2003). Response of seed-born fungi to fumigation with ethanedinitrile at various dosages. Proceedings of the Australian Postharvest Technical Conference, Canberra, 25-27 June 2003. CSIRO Stored Grain Research Laboratory, Canberra, 1-4.

53. Zakladnoy, G. A. (2018). Entomotoxicity of ethanedinitrile in wood. Entomological Review, 98(3), 272-274. https://doi.org/10.1134/S001387381803003X

54. Ducom, P. J. F. (2006). The return of fumigants. Proceedings $9^{\text {th }}$ International Working Conference on Stored Product Protection, Brazilian postharvest Association, Campinas, Brazil, 510-516.

55. Yunushodzaeva, S., Zakladnoy, G. A., Golik, M. G. (1973). Use of neutral gas mixtures to decontaminate grain in storage. In: New ways to increase the durability of the stored grain: Moscow: CNIITEI Minzag USSR. -33 p. (in Russian)

56. Golik, M. G., Zakladnoy, G. A., Yunushodzaeva, S. (1973). Use a neutral gas environment to decontaminate grain in storage. Overview. Elevator Industry Series. Moscow: CNIITEI Minzag USSR, 9-10. (in Russian)

57. Golik, M. G., Yunushodzaeva, S., Zakladnoy, G. A. (1974). The effect of a neutral gas environment on the death of insects at different temperatures and relative humidity. Materials from the VZIPP scientific conference. Moscow: VZIPP, 6-7. (in Russian)

58. Zakladnoy, G. A., Chekanov, A. A., Yunushodzaeva, S. (1974). Neutral gas environments are a means of controlling pests of stocks. Plants protection, 9, 58. (in Russian)

59. Zakladnoy, G. A., Yunushodzaeva, S. (1976). Use of neutral gas environments to control grain pests. The mill-elevator industry, 5, 33-35. (in Russian)

60. Zakladnoy, G. А., Голик, М. В., Yunushodzaeva, S. (1976). Use of neutral gas environments to disinfect grain. Scientific and technical reference collection. Elevator industry. Moscow: CNIITEI Minzag USSR. 1, 18. (in Russian)

61. Donahaye, E., Navarro, S., Rinder, M. (1994). The influence of temperature on the sensitivity of two nitidulid beetles to low oxygen concentrations. Proceedings $6^{\text {th }}$ International Working Conference on Stored Product Protection, CAB International, 88-90.

62. Koçak, E., Schlipalius, D., Kaur, R., Tuck, A., Ebert, P., Collins, P., Yilmaz, A. (2015). Determining phosphine resistance in rust red flour beetle, Tribolium castaneum (Herbst.) (Coleoptera: Tenebrionidae) populations from Turkey. Turkiye Entomoloji Dergisi, 39(2), 129-136. https://doi. org/10.16970/ted.17464

63. Daglish, G. J., Collins, P. J., Pavic, H., Kopittke, R. A. (2002). Effects of time and concentration on mortality of phosphine-resistant Sitophilus oryzae (L) fumigated with phosphine. Pest Management Science, 58(10), 10151021. https://doi.org/10.1002/ps.532

64. Bell, C. H. (1992). Time, concentration and temperature relationship for phosphine activity in tests on diapausing larvae of Ephestia elutella (Hubner) (Lepidoptera: Pyralidae). Pesticide Science, 35(3), 255-264. https://doi.org/10.1002/ps.2780350310
65. Nayak, M. K., Collins, P. J. (2008). Influence of concentration, temperature and humidity on toxicity of phosphine against strongly phosphine-resis tant psocid Liposcelis bostrychophila Badonnel (Psocoptera: Liposcelididae). Pest Management Science, 64(9), 971-976. https://doi.org/10.1002/ ps.1586

66. Nayak, M. K., Holloway, J. C., Pavic, H., Head, M., Reid, R., Collins, P. J. (2010). Developing strategies to manage highly phosphine resistant populations of rusty grain beetles in large bulk storages in Australia. Proceedings $10^{\text {th }}$ International Working Conference on Stored Product Protection, Julius-Kuhn-Archiv, 396-401.

67. APVMA, Australian Pesticide and Veterinary Medicine Authority, Product No 50177, ECO FUME$^{\oplus}$ Phosphine Fumigant. (2012). [Electronic resource: http; //services.apyma.gov.au./ Access date 18.01.2020].

68. Kaur, R., Subbarayalu, M., Jagadeesan, R., Daglish, G. J., Nayak, M. K., Naik, H. R., Ramasamy, S., Ebert, P. R., Schlipalius, D. I. (2015). Phosphine resistance in India is characterised by a dihydrolipoamide dehydrogenase variant that is otherwise unobserved in eukaryotes. Heredity, 115 (3), 188-194. https://doi.org/10.1038/hdy.2015.24

69. Chen, Z., Schlipalius, D., Opit, G., Subramanyam, B., Phillips, T. W. (2015). Diagnostic molecular markers for phosphine resistance in U.S. populations of Tribolium castaneum and Rhyzopertha dominica. PLoS ONE, 10(3), e0121343. https://doi.org/10.1371/journal.pone.0121343

70. Schlipalius, D. I., Valmas, N., Tuck, A. G., Jagadeesan, R., Ma Li, Kaur, R., Goldinger, A., Anderson, C., Jujiao Kuang, I., Zuryn, S., Mau, Y. S., Cheng, Q., Collins, P. J., Nayak, M. K., Schirra, H. J., Hilliard, M. A., Ebert, P. R. (2012). A core metabolic enzyme mediates resistance to phosphine gas. Science, 338(6108), 807-810. https://doi.org/10.1126/science. 1224951

71. Collins, P. J., Daglish, G. J., Bengston, M., Lambkin, T. M., Pavic, H. (2002) Genetics of resistance to phosphine in Rhyzopertha dominica (Coleoptera: Bostrichidae). Journal of Economic Entomology, 95(4), 862-869. https://doi.org/10.1603/0022-0493-95.4.862

72. Jagadeesan, R., Collins, P. J., Daglish, G. J., Ebert, P. R., Schlipalius, D. I. (2012). Phosphine resistance in the rust red flour beetle, Tribolium castaneum (Coleoptera: Tenebrionidae): Inheritance, gene interactions and fitness costs. PLOS ONE, 7(2), e31582. https://doi.org/10.1371/journal. phone.0031582

73. Schlipalius, D. I., Chen, W., Collins, P. J., Nguen, T., Reilly, P. E. B., Ebert, P. R. (2008). Gene interactions constrain the course of evolution of phosphine resistance in the lesser grain borer, Rhyzopertha dominica. Heredity, 100(5), 506-516. https://doi.org/10.1038/hdy.2008.4

74. Mau, Y. S., Collins, P. J., Daglish, G. J., Nayak, M. K., Pavic, H., Ebert, P. R. (2012). The $\mathrm{RPH}_{1}$ gene is a common contributor to the evolution of phosphine resistance in independent field isolates of Rhyzopertha dominica. PLoS ONE, 7(2), e31541. https://doi.org/10.1371/journal.pone.0031541

75. Mau, Y. S., Collins, P. J., Daglish, G. J., Nayak, M. K., Ebert, P. R. (2012). The $\mathrm{RPH}_{2}$ gene is responsible for high level resistance to phosphine in independent field strains of Rhyzopertha dominica. PLOS ONE, 7(3), e34027. https://doi.org/10.1371/journal.pone.0034027

76. Ridley, A. W., Hereward, J. P., Daglish, G. J., Raghu, S., Collins, P. J., Walter, G.H. (2011). The spatiotemporal dynamics of Tribolium castaneum (Herbst): Adult flight and gene flow. Molecular Ecology, 20(8), 1635-1646. https://doi.org/10.1111/j.1365-294X.2011.05049.x

\section{AUTHOR INFORMATION}

Gennady A. Zakladnoy - doctor of biological sciences, professor, leading research scientist, The Laboratory for Pest Protection and Sanitary Guarding of Grain and Grain Products, All-Russian Scientific and Research Institute for Grain and Products of Its Processing - Branch of V. M. Gorbatov Federal Research Center for Food Systems of RAS, 127434, Moscow, Dmitrovskoe shosse, 11. Tel.: +7-916-129-13-11, e-mail: vlaza@list.ru

ORCID: https://orcid.org/0000-0002-2037-7150

Completely prepared the manuscript and is responsible for plagiarism.

The author declares no conflict of interest.

Received 18.02.2020 Accepted in revised 10.03.2020 Accepted for publication 20.03.2020 